\title{
External financial security of the European Union member states outside the Eurozone
}

\author{
Piotr Siemiątkowski \\ Department of National and International Security, Nicolaus \\ Copernicus University \\ Poland \\ piotrs@umk.pl
}

\begin{abstract}
The article presents the characteristics of external financial security threats for the European Union Member States outside the Eurozone. Basing on the analysis of the key balance of payments accounts and several proposed financial security indicators, a ranking of the analyzed economies is suggested here. It is based on the Financial Security Index, which uses linear alignment methods. The research presented in this study proves that among the EU Member States outside the Eurozone, new members have been so far maintaining the parameters, considered in the synthetic measure, at a higher level as compared to the older members of the Union.
\end{abstract}

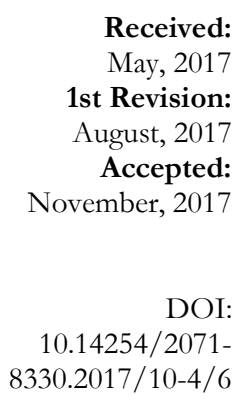

Received:

May, 2017

1st Revision:

August, 2017

Accepted:

November, 2017

DOI:

$10.14254 / 2071-$ $8330.2017 / 10-4 / 6$

Keywords: financial security, balance of payments, financial security index.

JEL Classification: F21, F36, F52

\section{INTRODUCTION}

The last decades brought about the unprecedented growth of dynamics in the events occurring at the international arena. It applies not only to both political and social events but also (and mainly) to economic ones. The contemporary world is basically a global environment. Actions and successes of some entities are tightly contingent upon the actions taken by the others. Nowadays, no economy can by fully autarchic. All the states (including even the most closed regimes such as the one in North Korea) are trading with each other. While the most intensive flows between the countries are those of capital and labour.

Behind all this, there is an infinite financial resource. A major part of it is detached from the real production means. What we witness these days is advanced financialization of the economies worldwide. The increased importance of financial institutions and their taking over the leading role in the sociopolitical life makes this sector dominate within the global environment. The role of money in economy was deeply disfigured. Money, being once invented to facilitate the exchange of commodities, now became a commodity itself. These days, people commonly trade money. Global IT platforms (e.g., Forex), which can be accessed by almost everybody worldwide, are functioning to facilitate and improve the process of making transactions of buying and selling currencies, being done solely for the purposes of speculation. Adding to 
that, numerous money flows within transnational corporations, in the relations between subsidiary and parent entities and within the network of capital markets transpire through financial markets during a week (some experts state this may take only 2 days). Thus, at financial markets there flows more money that the total value of the world export of commodities.

All the abovementioned properties of the contemporary global financial market generate a series of threats to financial security of particular countries. All the state structures are threatened with a series of significant financial dangers, the source of which is located in their external environments. Moreover, the majority of channels through which the said threats are disseminated remain out of local decision-makers' control.

The purpose of this paper is describing the external threats to financial security of the economies of the countries outside the Eurozone as well as ranking the financial security thereof. The choice of the research sample was prompted by (required by the assumed method) the necessity of ensuring the commensurability of the studied entities. From the viewpoint of external financial security, what comprised the major difference between the outlined group of states and the remaining part of the EU is a relatively autonomous monetary policy. One of its most fundamental external instruments in this regard is foreignexchange reserves, kept by central banks. Entering the Eurozone, on the other hand, implies moving monetary policy to the supranational level, and this practically means resigning from keeping bigger reserves.

In the first part of the paper, what was reviewed was the professional literature related to understanding the essence of financial security of a given state. Further, what was identified were key dangers to the external financial security of a state. Among those factors, such properties of the European Union Member States outside the Eurozone were selected that were successively taken advantage of in constructing a taxonomic synthetic measure. Hellwig's synthetic measure will allow, first, in the measurement of the external financial security of a state for taking into consideration multifarious properties of economies; and second, will enable us to compare the situation of the old and new EU Member States outside the Eurozone.

\section{LITERATURE REVIEW}

The financial security of a state is a contributing factor to its economic security. The latter is a derivative of the political and economic regime because the way of regulation by the politicians of the operations of economic entities and interrelation between them and state institutions as well as the principles of international relationships have an impact on the level of economic security of the state. What is key in his assurance is developing the economic strength. It requires a specific (smaller or greater) state intervention, at the very least - to guarantee the stability of economic growth (Fiedor, 2013).

The modern conception of economic safety should especially consider the dangers generated by the so-called global capitalism (Sulowski, 2013, p. 34). One of them is the loss of autonomy in economic policies pursued. In the era of globalization, internationalization of business enterprises and mobility of the means of productions, the loss of national sovereignty is often regarded as a necessary cost of foreign direct investments (Carbaugh, 2000, p. 81). However, the development of integration group caused the states to voluntarily delegate a part of their own sovereign rights to international institutions in return for the promise on latter's part to cooperate in overcoming international difficulties, oftentimes of global nature (Czaputowicz, 2004, p. 16).

Still, it is difficult to expect that this cooperation between the parties will be on equal terms. "Under the current international order - as shaped by the developed countries and established for the sake of maintaining their economic position - the power stemming from their competitive advantage allows them 
to infringe upon the sovereignty of other countries" (Yong, 2007, p. 68). Irrespective of whether they are acting within economic alliances or without them.

Although strategic aims of developing countries are principally compatible with the viable economic interests of developed countries, opening economies to an international markets causes economic sovereignty of weaker entities be more and more infringed upon - oftentimes under the veil of an economic aid (Stiglitz, 2007, p. 259-260). Globalization and the international economic order, generating economic dangers on the level of states, may contribute to destabilization of the national level of security, especially on the part of less developed countries (Ahmed, 2004). However, it looks as if, in the international realm, commonly setting the conditions favourable to the economic growth by many participants of the global markets gives rise to greater possibilities of achieving the adopted target of the level of security in comparison with being isolated and remaining a by-stander to global trends (Buzan, 1984).

Economic security signifies then such a state of a political regime and, being its consequence, economic regime which assures the freedom of actions on the part of business entities, the stabilization of the macroeconomic conditions under which the said businesses are run; and eventually, low beaurocracy and tax burden; the provisions of internal trade being regulated to such an extent that they can ensure comparable competitiveness and comparable share in international alliances increasing relative immunity to negative influences of external environment (Siemiątkowski, 2017).

Financial security is a key determinant of the economic security of the state. Being compared to all the flows of the factors of production, it is money and its substitutes that play the key role in contemporary global economy. As all the areas of security, this one can also be considered from the internal as well as from the external point of view.

The subject matter of the present study is the external financial security of the state. It means such a level of development of an economy and its international economic relations that can assure the financial stability of basic units (on the level of households and enterprises), financial system and state institutions against potential turmoil on the global market, resulting in the outflow of financial streams and the increase in the cost of debt service (Redo \& Siemiattkowski, 2017).

Yet, financial stability should not be identified with macroeconomic equilibrium (being connected with - among others - a legally specified level of public debt), but with the conditions under which there occurs no systemic risk (risk of infection), that is the situation in which a crisis harassing one country or a region becomes a direct cause of instability of the system in another country or a region or even reaches international proportions. That is why, financial stability is principally defined "negatively", that is as a lack of financial crisis" (Jurkowska-Zeidler, 2008, p. 85).

Internal economic security, on the other hand, concerns internal economic equilibrium, reliable mechanism of market competition and the ability to make use of endogenic factors of growth (Stachowiak et al 2014, p. 39).

In the above context, the most important aspects of financial security of the state comprise: an appropriate structure of international capital flows, the stability of financial sector, such a level of debt that does not increase the risk of investments (the external one, a public one and the banking sector as well as the enterprises and households) and such an amount of reserve assets that would increase the credibility (Siemiatkowski 2015, p.166). It means that the level of the external security of the economy is essentially determined by five key factors: "the network of financial security coupled with the structure of shareholding in banking sector, the level of the development of the economy as well as its competitiveness, a safe level of public debt allowing for its uninterrupted service, the efficiency of public institutions moving regulations to the sphere of the real national economy" (Raczkowski, 2014, p. 316); and it is finally determined by the amount and the structure of official reserve assets. "The totality of institutions and regulations aimed at protecting financial system from destabilization is a network of financial security” (Capiga 2011, p. 43). In 
the above-stated approach, what manifests itself is a strict relationship between financial stability, conceived of as an immunity to the repercussions of external financial shocks, and financial security.

\section{KEY DANGERS TO THE EXTERNAL FINANCIAL SECURITY OF EUROPEAN UNION MEMBER STATES OUTSIDE EUROZONE}

Searching for external dangers to the economic security of the state should commence with the analysis of the balance of payment. It is a basic statistical study containing the information on the balance of payment relative to external countries. The balance of payment is a balance of transactions concluded between the residents of one economy and the external entities (non-residents). Therefore, it constitutes an invaluable source of knowledge on the money inflows and outflows of a given economy.

According to the current directives of the International Monetary Fund (IMF), the balance of payment should consist of four accounts: current account, capital account and of the balance of errors and omissions. In principle, all of the above accounts may assume such proportions that would threaten the financial security of a state. That is why, what is important are not the conditions of particular accounts alone, but rather their mutual relations and their respective references to the remaining macroeconomic parameters.

From the point of view of stability of the economy's balance of payment, what is a key account is a current account. What is important is not only its balance but also its structure. What is usually the case is the current account deficit - particularly in developing countries undergoing their regime transformation. Scholars diverge on the issue of the acceptable level of deficit of current turnovers; however, there is common belief that the excessive outflow of money from the said account is harmful to the economy and threatens its financial security.

In the context of the external financial security of a state, in the structure of the balance of the current account, we should mainly distinguish two main issues. First, trade balance - the most important of the external accounts of any economy. Not to mention that it would be good if the deficit was not recorded thereon, what is important is its credibility. The problem which has been recently raised is the fact that in many countries what makes the picture of this account murky and vague is the so-called VAT gap. Experts point out that the statistical data related to export in many countries is exaggerated; what is worse, a major part of it is purely fictitious. This situation is caused by an enormous scale of fraud - among others - VAT fraud from purely fictitious transactions.

The second issue concerns the balance of primary income. In many less developed economies, upon them accession to the European Union, their respective net primary income started to grow rapidly. Obviously, it is partly connected with the increased proportions of operations on the part of transnational corporations. In practice, a major part of this balance may be a result of the so-called tax gap in CIT [Corporate Income Tax]. Foreign corporations, taking advantage of the so-called tax optimization, transfer their profits abroad, simultaneously not paying taxes while doing so (Ratajczak, 2017).

The next issue related to the external financial security is the shaping of capital account. In many countries which were in recent years admitted to the European Union in the last rounds of extending the number of member states, this account indicates a significance surplus. This is due to the increased inflow of means stemming from the structural funds dedicated to financing fixed assets, including enormous amounts dedicated to financing the modernization of communication infrastructure. Capital account in these countries become a stabilizer of the entire balance of payment. The problem arises at this moment when the inflow of funds may happen to get hampered. Such a state of affairs is not impossible since one of the biggest net payer in EU - Great Britain - is leaving the Union. Therefore, the means are going to be much less plentiful. Such a situation threatens the financial security especially of these countries in which positive net amount on the capital accounts serves to finance a big deficit on the current account. 
The next issue related to the external financial security of a state is the shaping of and the structure of the financial account of the balance of payment. Typically, it is exactly the net surplus on this account that finances a possible deficit of current turnovers. The surplus on this account is an indication of the foreign capital taking interest in making investments in a given economy. As the analysis of the statistical data conducted in particular countries shows, the relation between the records on this account and the said investments may be highly varied.

The last component of the balance of payment is the balance of errors and omissions. At the same time, this component is one of the most controversial balances of the entire balance of payment. Some radical opinions have it that this last component of the balance of payment is a reflection of illegal outflows of money from the economy. Still, the opinions thereupon diverge and the dominating belief is that the causes of rather significant net errors and omissions in the balance of payment are difficult to pinpoint; however, they are probably of rather complex character. Some analysts speculate that such a low balance of errors and omissions stem from an unreliable quality of data sources spread to central banks, from small entities not sharing their data or sharing them with some delay, and from the underestimation of the import of used cars; and finally, from the inaccuracy of estimating the income of the laborers working abroad and making money transfers to their respective native countries (it applies also to the foreigners working in a given country) (Parkiet, 2011).

As was already mentioned above, the key issue related to the estimation of the external financial security of the state are not merely the conditions of particular components of the balance of payments, but rather the relations between them. For instance, the same amount of the deficit of the balance of current turnovers being in one relation to the remaining components of the balance of payments may be regarded as relatively safe, whereas the said same deficit being in the other relation to the remaining components may seem nightmarish to the relevant decision-makers.

What is most important while estimating the external financial security will be the balance of the current account. Although there is no universal and non-fuzzy measure of the deficit of current turnovers which would allow for stating with confidence whether the balance is safe or not. The highly negative value of the said balance definitely generates the risk of discretely correcting the disequilibrium, which can exert an impact on the dynamics of the real national income. What matters then is the source of covering the said deficit. If the deficit of current turnovers is covered by the positive balance of foreign direct investments (FDI), the situation may be regarded as relatively stable. It is because FDIs are a sort of international assets of a relatively stable nature and of rather long-term planning horizon. What they are usually about is the necessity of the investor's involvement in building the infrastructure, employing labourers or negotiating tax reliefs with public authorities. So, there is a relatively small danger of the sudden back-off on the part of the investor and thus the outflow of the capital from the economy.

The situation seems to be less comfortable when the balance of direct investments does not entirely (or even partly) cover the deficit of current turnovers. Then, this deficit should be covered by the positive balance of foreign portfolio investments (FPI). Such a case is significantly less safe. It is because FPIs are relatively unstable kind of international assets. Indirect investor can easily withdraw the already employed means, thus simultaneously causing a sudden outflow of capital from the economy. If the balance of foreign investments does not cover the deficit on the current account, it can eventually be covered by the positive balance of the capital account. The evaluation of such a possibility particularly depends on the prospect related to the inflow of the capital onto this account.

The continuation of the analysis of the balance of payment seen from the angle of external dangers to the financial security of the state is the analysis of the value of the external debt on the part of national residents. The data related to this problem are the components of different accounts of the balance of payment; and that is why they should be summarized at one place. The external debt is an aggregate of 
financial liabilities of national debtors, the liabilities being owed to foreign creditors (governments, banks, organizations and other business entities), the said liabilities encompassing loans and borrowings as well as the liabilities arising from the issued debt securities.

If over a longer period, the entities of a given country incur more liabilities than provide credits, such an economy becomes the so-called debtor nation. If the opposite is the case (that is, for a given country there are more credits provided than received), this country becomes a creditor nation.

The main danger to the financial security of the state, stemming from its external debt, is the home economy's financial dependence on external entities. Such circumstances decrease the autonomy of the national economic policy and of the economic calculation of business enterprises and of households. The growing external liabilities decrease the credit worthiness and hamper the access to the capital as well increase its cost. The debtors are burdened with the cost of debt service, which causes the inefficient allocation of income (weaker funding of public services), it reduces the consumption (the lower level of satisfying social needs) and investments too. It entails the lowered capacity of the global economy and it results in the slower rate of development (Dynus, 2007), thus limiting the wealth of future generations.

For a more complete illustration of the external dangers to the financial security of the state, there remains the issue of stressing the problem of the so-called official reserve assets. For some time, the changes in them are accounted on the financial account of the balance of payment. Before, they were recorded in it as a separate account. Reserve assets are liquid external assets controlled by monetary authorities and serving to satisfy needs when it comes to financing the balance of payment, intervening in the exchange rates and strengthening the trust in the currency and home economy, the latter of which having a bearing on the credit worthiness of home business entities. Reserve assets include such instruments as: gold, securities, deposits and cash, SDR resources, reserve tranche position in IMF, financial derivatives and other claims (IMF, 2009, p. 113).

For many years, reserve assets are the main warranty of the external solvency of a given economy. Simultaneously, they are the key element of the system of the financial security of the state. Their significance grew considerably after the last financial crisis. The experience connected therewith conclusively proved that the on-the-fly monitoring of the country being exposed to the external dangers and the appropriate adjustments of one's own reserves thereto are unconditional necessities.

\section{METHODOLOGY}

In order to create a ranking of the EU Member States outside the Eurozone with respect to their respective external financial security, the present paper took advantage of the method of linear ordering. This sort of taxonomic analysis is a juxtaposition of the methods serving to estimate the level of the diversification of the objects of the study (that is economies) by dint of the closed set of statistical properties.

The first stage of construct exploited in the present study of synthetic measure is the in-depth analysis of properties describing objects. The analysis in this case is relatively simple. That is because diagnostic variables are the constituents of international assets and liabilities. In the conducted study one resigned from attributing coefficients to particular diagnostic variables.

The next state of constructing the synthetic measure is the standardization of properties. It may be done in a variety of ways. The method of selecting the standardization of properties is predicated upon the assumed method of determining the synthetic measure. Basically, the "procedures of the determination of the synthetic measure may be divided into two groups:

- non-model methods,

- model methods" (Ostasiewicz, 1998, p. 119). 
In the present study, the model method was employed, in which what is assumed is the existence of the model-patterned object (or simply stated: the pattern), against the benchmark of which the taxonomic distance between studied objects is determined. "The typical and the most usually employed method in practical research by dint of synthetic measure of that group of methods is Hellwig's measure (due to its original applications to study the economic growth that measure is also referred to as the measure of growth)"(Ostasiewicz, 1998, p.120).

In the case of employing Hellwig's measure, the standardization of properties follows according to the formula below

$$
x_{i j}=\frac{x_{i j}-\bar{x} j}{S_{j}}
$$

$x_{i j}-$ empirical values of $j$-property in i-object

$\bar{x} j$ - the arithmetic mean of $j$-property

$S_{j}-$ standard deviation of j-property.

The determination of the pattern involves the selection from the standardized matrices, by dint of the above model of properties, of the maximal value for stimulants or alternatively the minimal value for properties other than stimulants

$$
x_{0 k}=\left\{\begin{array}{l}
\max _{i} x_{i j} d l a j \in S \\
\min _{i} x_{i j} d l a j \notin S
\end{array}\right.
$$

The synthetic measure is the following value:

$$
d_{i}=1-\frac{d_{i 0}}{d_{0}}
$$

where:

$d_{i 0}$ - Euclidean distance between the object $x_{i}$ from the model object $x_{0}$,

$d_{0}$ - the critical distance of a given unit from the model.

Euclidean distance is calculated according to the following formula:

$$
d_{i 0}=\sqrt{\sum_{j=1}^{p}\left(x_{i j}-x_{0 j}\right)^{2}}
$$

Whereas the critical distance of the unit from the model is calculated as follows:

$$
d_{0}=\bar{d}_{0}+2 s_{d}
$$

where:

$\bar{d}_{0}$ - arithmetic mean of taxonomic distances:

$$
\bar{d}_{0}=\frac{\sum_{i=1}^{n} d_{i 0}}{n}
$$

$S_{d}$-standard deviation from taxonomic distances: 


$$
s_{d}=\sqrt{\frac{\sum_{i=1}^{n}\left(d_{i 0}-\bar{d}_{0}\right)^{2}}{n}} .
$$

The attempts to work out some integrated measures of security already took place in the past. The examples might be, to give but a few, Global Peace Index, Global Food Security Index, Global Cybersecurity Index or World Internal Security and Police Index. These are the measures of different types, aiming at quantifying various areas of a state's security. Less popular are the measures related to financial security. If they are studies at all, they relate to the security of individual entities (eg. Genworth Index for home economies) and in the case of states - they concentrate on the separate comparison of commonly known macroeconomic measures (eg. the level of public debt) and thereupon building consolidated indicators or else - on creating the so-called credit ratings (Tkalenko, 2013; Semjonowa, 2016). The issue of the external security of states has not yet been scrutinized from the angle of a synthetic measure.

\section{EMPIRICAL RESULTS AND DISCUSSION}

In order to create the taxonomic index of the external financial security (FSI) of the European Union Member States being outside the Eurozone, the eleven (enumerated below) properties of the economies were distinguished:

$\mathrm{X}_{1 \mathrm{t}}$ - the relation between the balance of the current account of the balance of payment to GNP,

$\mathrm{X}_{2 \mathrm{t}}$ - the relation of the balance of the capital account of the balance of payment to GNP,

$\mathrm{X}_{3 t}$ - the level of covering the deficit of the current account by the balance of direct investments,

$\mathrm{X}_{4 \mathrm{t}}-$ the level of covering the deficit of the current account by the aggregate of the balance of FDIs and FPIs,

$\mathrm{X}_{5 \mathrm{t}}$ - the balance of errors and omissions in relations to GNP,

$\mathrm{X}_{6 t}-$ the level of covering the liabilities of portfolio investments by the official reserve assets,

$\mathrm{X}_{7 \mathrm{t}}-$ the relation of official reserve assets to the import of commodities and services,

$\mathrm{X}_{8 \mathrm{t}}-$ external debt in relation to GNP,

$\mathrm{X}_{9 \mathrm{t}}-$ net international investment position in relation to GNP

$\mathrm{X}_{10 \mathrm{t}}$ - the resources of FDIs in relation to GNP,

$\mathrm{X}_{11 \mathrm{t}}$ - the resources of FPIs in relation to GNP.

All the properties apart from $\mathrm{X}_{5 \mathrm{t}}, \mathrm{X}_{8 \mathrm{t}}$ and $\mathrm{X}_{11 \text {, }}$ were recognized as stimuli. Because it is necessary for these properties to satisfy the requirement of the completeness of statistical data as well as their methodological homogeneity, the properties $\mathrm{X}_{3 t}, \mathrm{X}_{4 t}$ and $\mathrm{X}_{5 \mathrm{t}}$, were not considered while determining the synthetic measure of development. In the first two cases, what the problem involved was the fact that it was not the case that the deficit on the current account occurred in all the scrutinized countries. Therefore, it was impossible to unambiguously categorize the indicated properties. The reason why the property no. 5 was not considered was the fact that some of the analyzed countries did not discharge their statistical duty owed to EUTOSTAT or else - they published incomplete data.

The situation of the scrutinized countries with respect to these distinguished properties varied. It is little wonder because the economies remaining outside the Eurozone are differentially economically developed

First, it should be underlined that the deficit on the current account occurred only in three cases (Poland, Romania and Great Britain). Taking into account the fact that the group of countries under consideration are mainly developing economies, it is still a sort of surprise. As few as ten years ago (2006), 
the situation in this respect would be entirely different, that is, in most cases, the deficit on the current account would be recorded.

Such a situation has a bearing on the area of another set of properties, comprising the fiscal index of the external financial security. If a given economy is not harassed by the deficit on the current account, there is principally no need to finance it. Therefore, it is unjustifiable to juxtapose the properties $\mathrm{X}_{3 \mathrm{t}}$ and $\mathrm{X}_{4 \mathrm{t}}$ for they will not be commensurable.

After taking into consideration the properties that satisfy the criteria, the ranking of the EU Member States outside the Eurozone was created along the lines of the synthetic measure. This ranking is presented in table 1 together with the values of the index of the external financial security.

Table 1

The taxonomic index of the external financial security of the European Union Member States being outside the Eurozone (as at the end of 2016)

\begin{tabular}{|l|c|c|}
\hline \multicolumn{1}{|c|}{ State } & FSI & Rank \\
\hline Bulgaria & 0,635755182 & 1 \\
\hline Czech Republic & 0,529105478 & 2 \\
\hline Croatia & 0,505790929 & 3 \\
\hline Hungary & 0,501897149 & 4 \\
\hline Romania & 0,483249178 & 5 \\
\hline Poland & 0,430762241 & 6 \\
\hline Denmark & 0,412633714 & 7 \\
\hline Sweden & 0,372254916 & 8 \\
\hline Great Britain & 0,219515858 & 9 \\
\hline
\end{tabular}

Source: own calculations.

The ranking presented in table 1 demonstrates that, statistically speaking, the lowest level of the external financial security fell on Great Britain and Sweden. The more in-depth analysis of the data proves that the causes of this state of affairs are several and they do not fully overlap for both countries. In case of Great Britain, the main causes of such a low-rated position are, first, the unprecedented external debt in relation to GNP as well as the lowest values in most of the properties indicated in the present study. The only positive properties for Great Britain are the relation of its international investment position to its GNP and the ratio of FDI resources to GNP. However, in these cases British economy did not record the highest values in the scrutinized group. At the same time, it should be borne in mind that the statistics related to the level of external debt of Great Britain has been unavailable for some time now. Not publishing the data which is shared by the majority of the remaining EU Member States raises some doubts. Is it really the case that the level of liabilities of British business entities is not too high?

The case of Sweden is a little different. It did not record the deficit on the current account. This alone had an impact on the fact that Sweden and Great Britain differed considerably as to the value of the taxonomic measure of the growth.

Taxonomically speaking, after taking into consideration all the properties satisfying the criteria, the country which turned out to be most immune to the external dangers was Bulgaria, which achieved the highest value of the taxonomic measure of the growth among the scrutinized countries. The reason is high, and oftentimes even the highest, values of the distinguished properties among all the EU Member States outside the Eurozone. In practice, the only parameter that should be conceived of negatively is its relation between the international investment position to its GNP, the value of the relation being highly negative 
(not the lowest in this given group, though). It evidences the fact that Bulgarian economy is highly dependent on external funding. Another negative factor is the external debt of Bulgaria, which amounts to $76 \%$ of its GNP. With this result, Bulgarian economy finds itself somewhere in the middle in the ranking of all the countries under the present study.

The key conclusion drawn from the above analysis relates to the difference in the value of a synthetic measure between the old and new EU Member States. Old States occupy the bottom positions of the rating, assuming the lowest value of FSI (financial security index). Such considerable discrepancies in the values of this index may have stemmed from the strong internationalization of the economies of Great Britain, Sweden and Denmark. The so called new Member States of the EU, despite the fact that they are strongly involved in international trade, still do not catch up with the old Member States of the Union with respect to foreign investors' involvement in their respective economies, or with respect to their respective residents' involvement in foreign trade.

\section{CONCLUSION}

The development of the global financial market and its consequence - the growth of the global resources of capital, for which its owners search for still new investments - makes economies (especially the developing ones) get threatened with bigger and bigger external financial dangers. Maintaining a specified level of financial security calls for still bigger and bigger efforts on the part of public institutions and commercial entities with respect to managing international transactions. After all, many sources of financial dangers reside in international sphere, or even the global one, and they remain out of full control of the national decision centers.

What adds insult to injury is the growth of political risk, which is rising in the recent years. It mainly applies to the relations within the European Union; but it also applies to internal relations. The lack of stability in external and internal relations is an important factor strengthening the process of the interference of the threat to economic security of the state. (Siemiątkowski, 2017).

The phenomenon of the interference is particularly dangerous in the case of the occurrence of the unfavourable external conditions. The recurrence of the global financial crisis, in the case of one or the other speculative bubble bursting, may cause the exacerbation of particular threats and may cause the external balance of payment disequilibrium to do considerable harm in the national economic system.

The results of the taxonomic research presented in this study prove that among the EU Member States being outside the Eurozone, new member states has been so fair maintaining the parameters considered in the synthetic measure at a higher level than the old Member States of the Union. It is no surprise because the developing economies, due to the fact that investors take lesser interest in them, must pay attention to the external financial dangers. It is because they are to a higher degree vulnerable to the repercussions of the potential global crises and to the possible activities on the part of international speculators. The old Member States of the EU are highly developed economies. They boast high credibility in the eyes of international investors. Even in case of worse macroeconomic indicators, the turmoil on the global market do not usually in their case cause investors to beat a panic-struck retreat. These economies do not either have any difficulty with the acquisition of external funding (despite large proportions of the external debt).

A peculiar case in this respect is British economy. As is widely known, Great Britain is now undergoing the process of existing the EU structures. As is also known, it was the second country, after U.S.A., which experienced the aftermath of the last financial crisis most severely. These two facts put together and juxtaposed with the above-stated ranking should give an important signal for taking up some actions aimed at improving the external financial security of British economy.

The analysis stated above is merely a small contribution to more in-depth considerations of the problem hinted at in this paper. Many important issues, to take but two examples - the issue of variable exchange rates or the issue of international speculation - were not raised here at all. Still, the present work can constitute a point of departure for novel analyses of the level of financial security, or generally: the economic security of the state, the basis of which will 
be a phenomenon of the interference of threats ${ }^{1}$. It means that a separate study of particular types of threats posed at the security of the state yields only fragmented information. Nowadays, it is necessary to conduct the study of how particular threats interfere with each other.

\section{REFERENCES}

Ahmed, N.M. (2004). The Globalization of Insecurity: How the International Economic Order Undermines Human and National Security on a World Scale, Institute for Policy Research \& Development. Historia Actual Online, 5, 113-126.

Buzan, B. (1984). Economic Structure and International Security: the Limits of the Liberal Case. International Organization, 4(38), 597. DOI: 10.1017/S0020818300026886

Capiga, M. (2011). Wielowymiarowość bezpieczeństwa finansowego banku - na przykładzie polskich regulacji prawnych. Bezpieczny Bank, 3, 42-58.

Carbaugh, R.J. (2000). International Economics. Cincinnati, South-Western College Publishing.

Czaputowicz, J. (2004). Rola państwa w Unii Europejskiej. Warszawa, Centrum Europejskie Natolin.

Dynus, M. (2007). Globalny kryzys zadłużeniowy - analiza przyczynowo-skutkowa. Zeszyty Naukowe WSB we Wrocławiu, $8(8)$.

Fiedor, B. (2013). Błędy rynku a błędy państwa - regulacja rynkowa versus regulacja publiczna. Ekonomista, 2, 183-200.

Grabiński, T., Wydymus, S. \& Zeliaś, A. (1989). Metody taksonomii numerycznej w modelowaniu zjawisk spoteczno-gospodarczych. Warszawa, PWN.

IMF, (2009). Balance of Payments and International Investmets Position Manual, Sixth Edition. Washington.

Jurkowska-Zeidler, A. (2008). Bezpieczeństwo rynku finansowego. Ujęcie prawne. In D. Dziawgo (Ed.), Wspótczesne finanse. Stan i perspektywy rožoju rynku finansowego. Toruń: Wydawnictwo Naukowe Uniwersytetu Mikołaja Kopernika.

Kolenda, M. (2006). Taksonomia numeryczna. Klasyfikacja, porzadkowanie i analiza obiektów wielocechowych. Wrocław, Wyd. AE we Wrocławiu.

Nowak, E. (1990). Metody taksonomiczne w klasyfikacji obiektów społeczno-gospodarczych. Warszawa, PWE.

Ostasiewicz, W. (1998). Statystyčne metody analizy danych. Wrocław, Wydawnictwo Akademii Ekonomicznej im. Oskara Langego we Wrocławiu.

Parkiet, (2011). Jest kilka teorii dotyczacych salda btęón i opusz̨zeń. Retrieved August 18, 2017 from http://www.parkiet.com/Gospodarka----Kraj/303319722-Jest-kilka-teorii-dotyczacych-salda-bledow-iopuszczen.html

Raczkowski, K. (2014). Bezpieczeństwo finansowe. In J. Płaczek (Ed.), Ekonomika beąpieczeństwa państwa w zarysie. Warszawa, Difin.

Ratajczak, M. (2017). Luka CIT niemal tak wysoka jak VAT. To zagrożenie dla bezpieczeństwa budżetu i państwa. Retrieved March 30, 2017, from https://www.money.pl/gospodarka/wiadomosci/artykul/luka-vat-luka-citunikanie-opodatkowania,238,0,2281454.html

Redo, M. \& Siemiątkowski, P. (2017). Zewnętrzune bezpieczeństwo finansowe państwa. Toruń, Uniwersytet Mikołaja Kopernika. doi: 10.12775/TIS.2017.100

Semjonowa, N. (2016). Financial Security in the Baltic States: Comparison with Selected EU Countries. Economics and Business, 29.

Siemiątkowski, P. (2015), Uzależnienie finansowe jako zagrożenie bezpieczeństwa ekonomicznego państwa. Toruń, Wydawnictwo Naukowe Uniwersytetu Mikołaja Kopernika.

Siemiątkowski, P. (2017). Interferencja zagrożeń z̧ewnętræ̨nego bezpieczeñstwa ekonomicz̨nego państwa. (in press).

\footnotetext{
1 The phenomenon observable in nature involves the emergence of the derivative amplified distribution (consistent with the business cycle) of the amplitude of threat, due to the interference of two or more threats. The stable interference of the threats is contingent upon the correlation thereof
} 
Stachowiak, Z., Kurek St. \& Kurek Syl. (2009). Beapieczeństwo ekonomiczne Ržeczypospolitej Polskiej. Retrieved March 30, 2017, from http://adamkorcz.w.interia.pl/ekon.pdf

Stiglitz, J.E. (2007). Wirja sprawiedliwej globalizacji. Propozycje usprawnień. Warszawa, Wydawnictwo Naukowe PWN.

Sulowski, S. (2013). O niektórych problemach bezpieczeństwa wewnętrznego RFN. In S. Sulowski (Ed.), Problemy bezpieczeństwa wewnetrznego w mybranych państwach. Warszawa, Dom Wydawniczy ELIPSA.

Tkalenko, S. (2013). Financial Security of the State in Terms of Globalization Processes Escalation. International Economic Policy, 1 (18).

Yong, J. (2007). Economic Security: Redressing Imbalance. China Security, 3(2).

Zeliaś, A. (Ed.). (1991). Ekonometria przestrzenna. Warszawa, PWE. 